\title{
Experience in managing a patient with a complicated course of SARS-COV-2 infection: early pulmonary rehabilitation and prevention of pulmonary fibrosis (clinical case)
}

\author{
Roman A. Bontsevich 1,2, 5, Yana R. Vovk ${ }^{3,5}$, \\ Anna V. Adonina 1, 5 , Liliya V. Solovyova 4, 5 \\ ${ }^{1}$ Children's medical center «Azbuka zdorovya», \\ 37a Shchorsa St., Belgorod, 308024, Russia; \\ ${ }^{2}$ Outpatient Clinic «Lyubimyy doctor», \\ 33 Yunosti Blvd., Belgorod, 308031, Russia; \\ ${ }^{3}$ Clinical and diagnostic center «Meditsina $31 »$, \\ 133g Bogdana Khmelnitskogo Ave., Belgorod, 308002, Russia; \\ ${ }^{4}$ Outpatient Clinic «Garmoniya zdorov'ya» LLC «MAKSBelmed», \\ 34 Pushkina St., Belgorod, 308015, Russia; \\ ${ }^{5}$ Belgorod National Research University, \\ 85 Pobedy St., Belgorod, 308015, Russia \\ E-mail: bontsevich@bsu.edu.ru
}

\begin{abstract}
Over the past two decades the world community has been shocked by the three largest coronavirus pandemics, each of which, despite the similarity of clinical symptoms in many aspects, has its own differences. This fact significantly complicates the diagnosis and treatment of new virus strains, which leads to a forced delay in early diagnosis and treatment of the disease, as well as the impossibility of suppressing the epidemic at the initial stages of its development.

The article presents the clinical case of a complicated course of a new coronavirus infection COVID-19 from the practice of a pulmonologist. There is data on the tactics of managing the patient until the visit to the pulmonologist. Minor changes are observed only in the auscultatory picture among physical data. Certain changes in laboratory and instrumental parameters are noted during the treatment of the patient. An important role in the diagnosis of the disease was played by the methods of enzyme immunoassay and polymerase chain reaction, as well as spiral computed tomography (SCT) of the chest, which made it possible to detect lesions, diagnose excessive consolidation (formation of pneumofibrosis) and its regression in dynamics against the background of active treatment. Spirometry made it possible to assess lung function over time. In the treatment were used drugs with anticoagulant and anti-fibrotic activity (new oral anticoagulants - apixaban (Eliquis ${ }^{\circledR}$ ), a polyenzyme drug - Wobenzym ${ }^{\circledR}$ and enzyme - bovgialuronidase azoxymer $\left(\right.$ Longidaza $\left.{ }^{\circledR}\right)$ ), together with a set of antioxidant vitamins and minerals, and there was an improvement in lung function.

The scientific community is carrying out a large-scale work to find new approaches in the treatment of coronavirus infection (COVID-19), however, the majority of the developed diagnostic and treatment methods are currently under study, while an ordinary doctor needs to prescribe a suitable therapy for a patient here and now.
\end{abstract}

Keywords: coronavirus, coronavirus infection, COVID-19, clinical case, anti-fibrotic therapy.

For citation: Bontsevich R.A., Vovk Y.R., Adonina A.V., Solovyova L.V. 2020. Experience in managing a patient with a complicated course of SARS-CoV-2 infection: early pulmonary rehabilitation and prevention of pulmonary fibrosis (clinical case). Challenges in Modern Medicine, 43 (3): 365-372 (in Russian). DOI: 10.18413/2687-0940-2020-43-3-365-372 


\title{
Опыт ведения пациента с осложненным течением SARS-COV-2 инфекции: ранняя легочная реабилитация и профилактика пневмофиброза (клинический случай)
}

\author{
Р.А. Бонцевич ${ }^{1,2,5}$, Я.Р. Вовк ${ }^{3,5}$, А.В. Адонина ${ }^{1,5}$, Л.В. Соловьёва ${ }^{4,5}$ \\ ${ }^{1}$ Детский медицинский центр «Азбука здоровья», Россия, 308024, г. Белгород, ул. Щорса, 37a; \\ ${ }^{2}$ Клиника «Любимый доктор», Россия, 308031, г. Белгород, бульвар Юности, 33; \\ ${ }^{3}$ Клинико-диагностический центр «Медицина $31 »$, \\ Россия, 308002, г. Белгород, пр. Богдана Хмельницкого, 133г; \\ ${ }^{4}$ Многопрофильная поликлиника «Гармония здоровья» ООО «МАКСБелмед», \\ Россия, 308015, г. Белгород, ул. Пушкина, 34; \\ ${ }^{5}$ Белгородский государственный национальный исследовательский университет, \\ Россия, 308015, г. Белгород, ул. Победы, 85 \\ E-mail: bontsevich@bsu.edu.ru
}

\begin{abstract}
Аннотация. За последние два десятилетия мировое сообщество потрясли три крупнейшие пандемии коронавирусной инфекции, каждая из которых, несмотря на схожесть клинической симптоматики во многих аспектах, имеет собственные характерные отличия. Этот факт значительно затрудняет диагностику и лечение вновь выявленных штаммов вирусов, что приводит к вынужденному промедлению в отношении раннего обнаружения и терапии заболевания, а значит и невозможности подавления вспышки эпидемического масштаба на начальных стадиях ее развития.

B статье представлен клинический случай осложненного течения новой коронавирусной инфекции COVID19 из практики врача-пульмонолога. Имеются данные о тактике ведения пациента до момента обращения. Среди физикальных данных незначительные изменения наблюдаются только в аускультативной картине. В ходе лечения пациента отмечаются выраженные изменения лабораторных и инструментальных показателей. Важную роль в диагностике заболевания сыграли методы иммуноферментного анализа и полимеразной цепной реакции, а также спиральная компьютерная томография (СКТ) органов грудной клетки, позволившая обнаружить очаги поражения, диагностировать избыточную консолидацию (формирование пневмофиброза) и ее регресс в динамике на фоне активного лечения. В лечении были применены препараты, обладающие антикоагулянтной и противофиброзной активностью (новый оральный антикоагулянт - апиксабан («Эликвис» $®)$, полиферментный препарат - Вобэнзим ${ }^{\circledR}$ и фермент Бовгиалуронидаза азоксимер (Лонгидаза®)), на фоне применения которых, совместно с набором антиоксидантных витаминов и минералов, наблюдалось улучшение легочной функции.

Научное сообщество ведет масштабную работу по поиску новых подходов в лечении коронавирусной инфекции (COVID-19), однако основная проблема заключается в том, что большинство разрабатываемых методов диагностики и лечения в настоящий момент находятся на стадии изучения, тогда как рядовому врачу назначить подходящую терапию пациенту необходимо здесь и сейчас.
\end{abstract}

Ключевые слова: коронавирус, коронавирусная инфекция, COVID-19, клинический случай, противофиброзная терапия.

Для цитирования: Бонцевич Р.А., Вовк Я.Р., Адонина А.В., Соловьёва Л.В.2020. Опыт ведения пациента с осложненным течением SARS-CoV-2 инфекции: ранняя легочная реабилитация и профилактика пневмофиброза (клинический случай). Актуальные проблемы медицины, 43 (3): 365-372. DOI: 10.18413/2687-0940-2020-43-3-365-372

\section{Introduction}

The current coronavirus infection (COVID-19), caused by a previously unknown strain of the SARS-CoV-2 coronavirus, can rightfully be considered a public health emergency. It is noteworthy that before the outbreak of acute respiratory syndrome (SARS-CoV), which occurred in 2003 in southern China and killed one in ten infected people, coronaviruses were not considered highly pathogenic for humans [Sifuentes-Rodríguez et al., 2020]. Nine years later, in 2012, Middle East Respiratory Syndrome (MERS-CoV) was diagnosed in Saudi Arabia, with a fatality rate of $35 \%$ and it was 
higher than SARS-CoV [World Health Organization]. Both of these outbreaks drew the attention of the medical community to the group of coronaviruses and allowed them to be considered as potential factors in the development of epidemic diseases.

The new coronavirus infection becomes the third chronologically pandemic, the pathogen of which has infected more people than either of its two predecessors. Although the death rate is only 2-3\%, which is lower than the rate of the outbreak caused by MERS-CoV in 2012, SARS-CoV-2 will cause many more deaths due to the significant spread of the virus [Guarner et al., 2020].

The study and development of new effective treatments for COVID-19 have brought together leading scientists around the world to fight the pandemic. Many published research results aim to study the structure of the virus empirically, to explain the nature and mechanism of action of an infectious agent, which undoubtedly helps in the correct selection of the necessary drugs, many of which exist on the pharmaceutical market and are recommended as a therapy for other well-known nosologies [Zhan et al., 2020; Soldatov et al., 2020; Jin et al., 2020]. But even despite universal efforts to eliminate the pandemic of COVID-19, the question of its effective treatment is still open.

\section{Case Report}

A 58-years-old patient applied on 30 July 2020 for an outpatient visit to a pulmonologist with complaints of coughing, shortness of breath with moderate physical exertion and general weakness.

From the anamnesis: the patient considers himself ill since 3 July 2020, when the following symptoms first appeared: coughing, fever up to $37.5^{\circ} \mathrm{C}$. On 5 July 2020 the patient's condition worsened - there was a febrile temperature, shortness of breath and dyspnea increased. The patient was admitted to the Regional infectious clinical hospital named after E.N. Pavlovsky in Belgorod. Considering the conclusion of the spiral computed tomography (SCT) of the chest, which revealed extensive ground-glass opacity lung lesions (the lesion volume was about $50 \%$, which corresponds to the third (severe) degree of CT), as well as a positive result of the examination of the nasopharyngeal swab on COVID-19 by the polymerase chain reaction analysis, a new coronavirus infection (COVID-19) of moderate course was diagnosed.

The severity of the disease's course can be can be traced by the laboratory parameters of the patient's analyzes obtained in the hospital. On the day of the patient's admission to the hospital (05.07.2020), lymphopenia is noted in the complete blood count (19\%), the maximum decrease in lymphocytes is observed on the fourth day of hospitalization (08.07.2020) - 13\%, then the indicator increased and by the thirteenth day reached the lower limit of the normal $-20 \%$. In addition, on the second day of hospital treatment the patient had leukopenia - the number of white blood cells was $3,5^{*} 10^{9} / 1$. Changes indicating the severity of the patient's condition are also observed in the biochemical analysis and blood clotting tests: an increase of CRP (05.07.2020 - 12,8 mg/l, 06.07.2020 - 17,9 mg/l, 08.07.2020. - 12,6 mg/l, 14.07.2020 - 6,3 mg/l, 17.07.2020. - 5,2 mg/l, 23.07.2020 - 5,4 mg/l), fibrinogen $(05.07 .2020$ - 4,21 g/l, 06.07.2020 - 4,0 g/l, 08.07.2020 -5,47 g/l, 14.07.2020 - 3,65 g/l, 17.07.2020 - 3,26 g/l, 23.07.2020 - 6,93 g/l), a positive D-dimer is noted from 06.07.2020 to 17.07.2020.

The patient was hospitalized from 5 to 24 July 2020, the prescribed therapy included: antimicrobial drugs (ceftriaxone, azithromycin), fraxiparine, umifenovir («Arbidol@»), ambroxol, dexamethasone, aminophylline, humidified oxygen inhalation. On 24 July 2020, the patient was discharged from the hospital with positive clinical dynamics and three negative results of nasopharyngeal swabs on COVID-19.

On the repeated SCT of the chest (25 July 2020), in comparison with the previous study (5 July 2020) negative dynamics was found in the form of pulmonary consolidation in the place of the previous ground-glass opacity lesions, and also revealed the absence of fresh lesions (Fig. 1-2). In general, the current state of the lungs was accompanied by a high risk of transition to pneumofibrosis, which was the reason for the patient's visit to a pulmonologist.

The patient also reported that he had the following chronic diseases: gouty arthritis (for which he took once betamethasone («Diprospan $® »)$ 28/7 and colchici autumnali seminum extractum 
(«Colchicum-dispert $\left.\AA^{\circledR} »\right)$ ), hypertension (does not take permanent antihypertensive therapy). In addition, the patient's smoking experience in the past is more than 30 years.

Physical examination of the patient at the time of the visit: general condition is satisfactory, body temperature is $36,8^{\circ} \mathrm{C}$, percussion - clear pulmonary sound, auscultatory - harsh breathing, no rhonchus; respiratory rate $=18$ ', SpO2 $-95 \%$ (when performing moderate physical activity - the level drops to $88-90 \%$ ), $\mathrm{HR}=$ Pulse $=88$ beats per min, BP: $\mathrm{D}=\mathrm{S}-130 / 90 \mathrm{~mm} \mathrm{Hg}$.

Based on the patient's complaints, the clinical picture of the disease, the data of an objective examination, as well as the results of previous laboratory and instrumental diagnostic methods, a clinical diagnosis was made: Transferred confirmed SARS-COV2 (COVID) - infection (07.2020; $\mathrm{SCT}+$ and RNA + , a/b - unspecified) with the 2-3rd degree of CT lung lesions, complicated course with the formation of pneumofibrosis. RF 0.

Concomitant diagnosis: Gout, acute gouty arthritis on big right toe. Arterial Hypertension, grade 2, uncontrolled hypertension, a cardiovascular disease risk 3, Chronic Heart Failure 1. FC 1.

The patient was recommended the following examination plan: a complete blood count, a C-reactive protein (CRP) test, a coagulogram with the determination of D-dimer, control of the level of uric acid once a week, determination of IgG antibodies to coronavirus by enzyme immunoassay, determination of vitamin D, SCT of the chest in dynamics after 1 month from the previous one.

A pulmonary function test (PFT) was carried out at an outpatient visit (Spirometer Contec SP70B, ECCS report). Results: PEF 7.71 - $85 \%$ (due - 9.02), FEV1 3.48 - $92 \%$ (due - 3.78), FVC 4.55 - $95 \%$ (due - 4.81), FEV1/FVC $76.5 \%$. Thus, no significant violations of the PFT were detected during spirometry, but there is a tendency towards a decrease in baseline indicators.

The patient was prescribed treatment: bovgialuronidase azoxymer («Longidaza $\left.{ }^{\circledR} »\right)$ 3,000 IU I.M 1 time in 5 days for 5 days; polyenzyme drug (pancreatin + papain + rutoside trihydrate + bromelain + trypsin + lipase + amylase + chymotrypsin) - «Wobenzym ${ }^{\circledR}$ » 3 tablets 3 times a day for 1 month; apixaban («Eliquis $(\circledR ») 5 \mathrm{mg} \times 2$ times a day - up to 1 month; atorvastatin

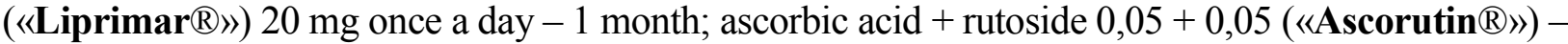

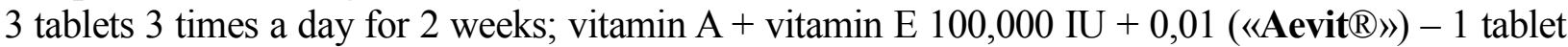
3 times a day for 2 weeks; zinc preparations $25 \mathrm{mg} 1$ tablet per day -2 weeks; Omega-3 fatty acids («Omacor $\left.{ }^{\circledR} »\right) ~ 1,0$ g x 1 time per day - 1 month; vitamin D preparations 5000 IU per day - 1 month; amlodipine + indapamide («ArifAM $\left.{ }^{\circledR} »\right)$ ) 5/1,5 mg - 1 tablet in the morning; bisoprolol + perindopril ( $\langle$ Prestilol $\AA ») 5 / 5 \mathrm{mg}-1 / 2$ tablet in the evening; 10 sessions of chest massage, breathing exercises, contrast shower, cold training. In addition, the patient is advised to continue the treatment of gout. The patient was prescribed a second appointment with a pulmonologist after 15 days.

At the next appointment, on 14 August 2020, the patient did not complain and noted an improvement in his general condition. The objective picture did not change significantly: the general condition is satisfactory, the body temperature is $36.8^{\circ} \mathrm{C}$. Above the lungs: percussion - pulmonary sound, auscultatory - harsh breathing, no rhonchi; breathe rate $=18$ ', $\mathrm{SpO} 2-97 \%$, $\mathrm{HR}=$ Pulse $=82$ beats $/ \mathrm{min}, \mathrm{BP}: \mathrm{D}=\mathrm{S}-130 / 80 \mathrm{~mm} \mathrm{Hg}$.

Laboratory parameters of blood serum (31/07/2020): leukopenia $-3,4 \times 10^{9} / 1$ (reference interval (RI) - 4,0-9,0 × 109/1), increased levels - CRP - 15,5 mg/l (RI $-0-5 \mathrm{mg} / \mathrm{l})$, uric acid $564 \mu \mathrm{mol} / \mathrm{l}(\mathrm{RI}-142-416 \mu \mathrm{mol} / \mathrm{l})$, activated partial thromboplastin time (APTT) $-37,3 \mathrm{~s}$ (RI - 25-35 s), fibrinogen - 4,1 g/l (RI - 1,8-4,0 g/l), as well as deficiency of vitamin D - 21,8 $\mathrm{ng} / \mathrm{l}$. The ELISA method revealed the titers of IgG antibodies to the SARS-CoV-2 coronavirus.

There is a normalization of indicators in the analyzes dated 12.08.2020: leukocytes 4,1 $\times 10^{9} / 1, \mathrm{CRP}-2,8 \mathrm{mg} / \mathrm{l}, \mathrm{APTT}-31,3 \mathrm{~s}$, fibrinogen $-2,85 \mathrm{~g} / \mathrm{l}$.

After one month the patient was recommended to repeat the following diagnostic procedures: $\mathrm{CBC}, \mathrm{CRP}$ and uric acid study, coagulogram with D-dimer determination. SKT of the chest 20.08.2020. The previously prescribed treatment is to continue.

On August 21, the patient was re-admitted with the results of SCT (Fig. 1-2). The patient has no complaints; he receives the recommended treatment. According to the SCT results, there is a 
positive trend. An objective examination revealed no pathological changes. A PFT (Spirometer «Contec SP70B», ECCS report) was carried out at an outpatient visit, the results of which are shown in Table 1.

Table 1

Таблица 1

Dynamics of main spirometric indicators

Динамика спирометрических показателей

\begin{tabular}{|l|c|c|c|c|}
\hline & Initial results, 30/07/2020 & Due results: & $21 / 08 / 2020$ & changes \% (30/07-21/08) \\
\hline PEF ( \%) & $85 \%$ & & $92 \%$ & $+7 \%$ \\
\hline FEV1 $(1-\%)$ & $3,48-92 \%$ & 3,78 & $4,21-111 \%$ & $+19 \%$ \\
\hline FVC $(1-\%)$ & $4,55-95 \%$ & 4,81 & $5,77-120 \%$ & $+25 \%$ \\
\hline FEV1/FVC $(\%)$ & $76 \%$ & & $77 \%$ & \\
\hline
\end{tabular}

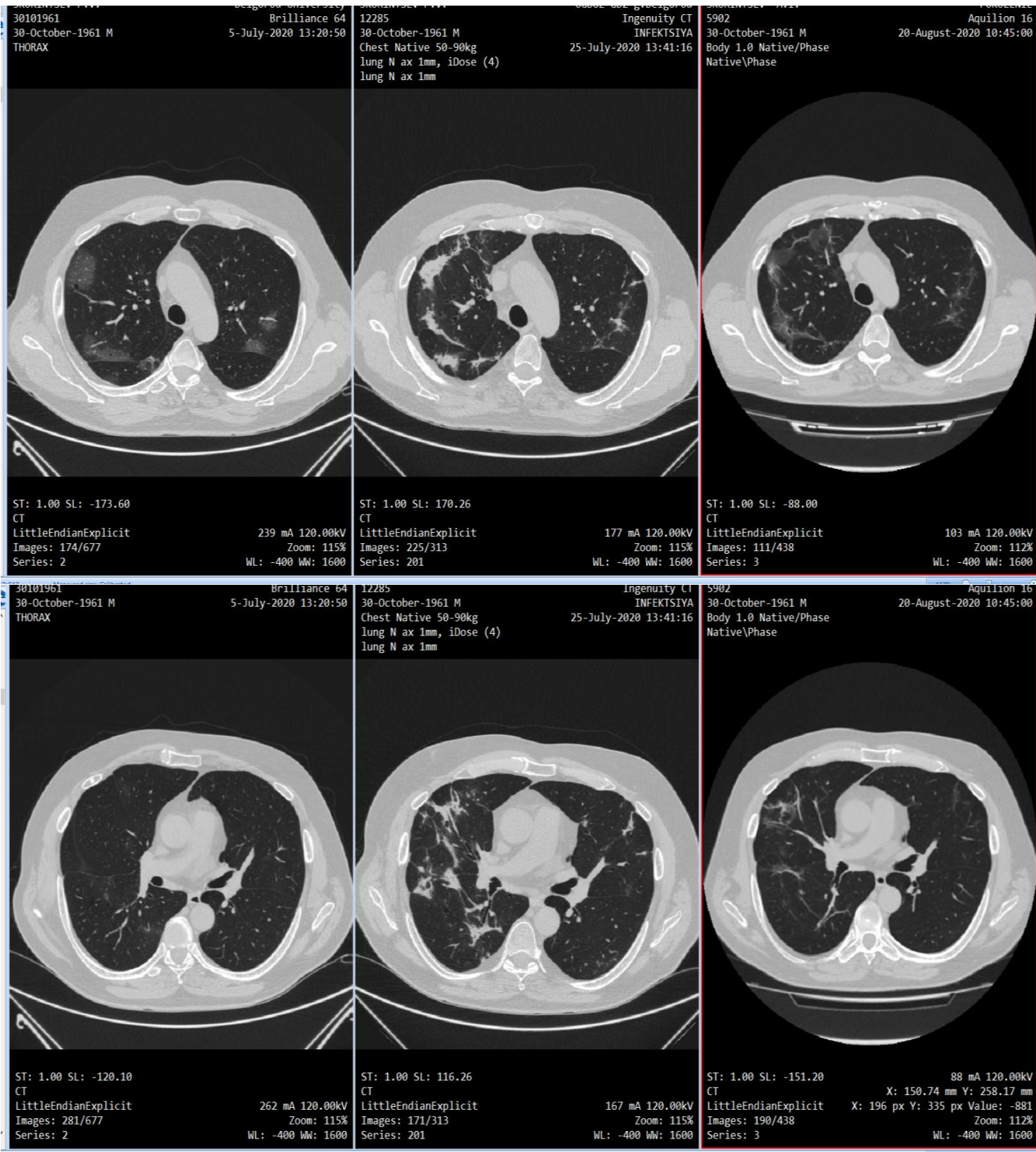

Fig. 1-2. Dynamics of the SCT picture: onset (3rd day of illness), significant consolidation (risk of pneumofibrosis) (23rd day), state on the background of active therapy (48th day)

Рис. 1-2. Динамика СКТ-картины: начало (3-й день болезни), значительная консолидация (23-й день), состояние на фоне активной терапии (48-й день) 
There was a significant improvement in the key spirometric parameters in dynamics, which objectively indicates an improvement in pulmonary function. The dynamics of key laboratory parameters for the entire observation period is shown in Table 2.

Table 2

Таблица 2

Dynamics of key laboratory markers

Динамика ключевых лабораторных маркеров

\begin{tabular}{|l|c|c|c|c|c|c|c|c|}
\hline & $05 / 07$ & $06 / 07$ & $08 / 07$ & $14 / 07$ & $17 / 07$ & $23 / 07$ & $31 / 07$ & $12 / 08$ \\
2020 & 2020 & 2020 & 2020 & 2020 & 2020 & 2020 & 2020 \\
\hline Leukocytes $\left(10^{9} / 1\right)$ & 4,8 & 3,5 & 5,9 & 5,9 & 6,8 & 6,4 & 3,4 & 4,1 \\
\hline Lymphocytes ( \%) & 19 & 18 & 13 & 17 & 20 & 21 & & 26 \\
\hline CRP (mg/l) & 12,8 & 17,9 & 12,6 & 6,3 & 5,2 & 5,4 & 15,5 & 2,8 \\
\hline Fibrinogen (g/l) & 4,21 & 4,0 & 5,47 & 3,65 & 3,26 & 6,93 & 4,1 & 2,85 \\
\hline D-dimer & $\begin{array}{l}\text { Negative } \\
\text { reaction }\end{array}$ & $\begin{array}{l}\text { Positive } \\
\text { reaction }\end{array}$ & & $\begin{array}{c}\text { Positive } \\
\text { reaction }\end{array}$ & $\begin{array}{l}\text { Positive } \\
\text { reaction }\end{array}$ & & & 0,23 \\
\hline
\end{tabular}

Final clinical diagnosis: Transferred confirmed SARS-COV2 (COVID) - infection (07.2020; SKT + and RNA +, a/b +) with the 2-3rd degree of SCT lung lesions, complicated course with the formation of pneumofibrosis. convalescence phase (positive SCT dynamics). RF 0.

Concomitant diagnosis: Gout, acute gouty arthritis on big right toe. Vitamin D deficiency. Arterial Hypertension, grade 2, controlled hypertension, a cardiovascular disease risk 3, Chronic Heart Failure 1. FC 1.

The patient was recommended to perform SCT of the chest - control - after 3-6 months. The pulmonologist appointed scheduled pneumococcal vaccination and vaccination against seasonal influenza on 27th August 2020. The course of intramuscular injections of the «Longidaza» should be extended up to a total of 15 injections, and the «Wobenzym» administration should be extended to a total course of 1,5 months, the previously prescribed treatment should be continued in full within the specified time frame.

\section{Conclusions}

Thus, on the one hand, the authors understand that at the moment there are no approved methods of preventive and therapeutic anti-fibrotic therapy of the consequences of COVID. On the other hand, in the interests of the patient, it is necessary to use and select options with a possible anti-fibrotic effect among the drugs that have such or similar properties in the instructions, in order to preserve and restore the respiratory function of the lungs.

In total, from our experience, schemes with the use of potentially anti-fibrotic agents are quite highly effective. We emphasize that this is still according to our observations, without large-scale research. We note that SCT of the chest and spirometry in dynamics are of practical use for assessing the degree of damage and restoration of pulmonary function.

At this time, in the acute and subacute phase of the mild course of SARS-CoV-2 infections, from our practical experience, the most effective treatment method is considered to be the use of new oral anticoagulants (significant experience with apixaban), in combination with polyenzyme drugs («Wobenzym $\AA »-$ in the subacute phase, and «Flogenzyme $(\AA)-$ in the early phase of the disease), if the course of the disease is complicated - in combination with «Longidase ${ }^{\circledR} »($ bovhyaluronidase azoxymer); it is also necessary to prescribe vitamins with antioxidant and angioproductive properties, such as A, E, C, routine, omega-3, vitamin $\mathrm{D}$. In addition to new oral anticoagulants, it is possible to take (and we have a positive experience with) low molecular weight heparins and sulodexide. In some situations, antibiotics (azithromycin or cefditoren) and/or alpha-interferon were added to the treatment regimen.

The authors hope that their practical experience and observations can be useful for colleagues in other regions and for conducting further research on effective tactics for managing SARS-CoV-2 infection. 


\section{Conflict of interest}

The authors declare no conflict of interest.

\section{References}

1. Sifuentes-Rodríguez, Erika, and Deborah Palacios-Reyes. 2020. «COVID-19: The outbreak caused by a new coronavirus». «COVID-19: la epidemia causada por un nuevo coronavirus». Boletin medico del Hospital Infantil de Mexico, 77 (2): 47-53. doi:10.24875/BMHIM.20000039.

2. World Health Organization. Middle East respiratory syndrome coronavirus (MERS-CoV). https://www.who.int/ emergencies/mers-cov/en/. Accessed August 22, 2020.

3. Guarner, Jeannette. 2020. «Three Emerging Coronaviruses in Two Decades». American journal of clinical pathology, 153 (4): 420-421. doi:10.1093/ajcp/aqaa029.

4. Zhan W.Q., Li M.D., Xu M., Lu Y.B. 2020. «Successful treatment of COVID-19 using extracorporeal membrane oxygenation, a case report». Eur. Rev. Med. Pharmacol. Sci., 24 (6): 3385-3389. doi: 10.26355/eurrev_202003_20705.

5. Soldatov V.O., Kuberkina M.V., Silaeva Yu.Yu., Bruter A.V., Deykin A.V. 2020. «On the way from SARS-CoV-sensitive mice to murine COVID-10 model». Research Results in Pharmacology 6 (2): 1-7. https://doi.org/10.3897/rrpharmacology.6.53633.

6. Jin Y.H., Cai L., Cheng Z.S. 2020. «A rapid advice guideline for the diagnosis and treatment of 2019 novel coronavirus (2019-nCoV) infected pneumonia (standard version)». Mil. Med. Res. 7 (1): 4. doi:10.1186/s40779-020-0233-6.

\section{Список литературы}

1. Sifuentes-Rodríguez, Erika, and Deborah Palacios-Reyes. 2020. «COVID-19: The outbreak caused by a new coronavirus». «COVID-19: la epidemia causada por un nuevo coronavirus». Boletin medico del Hospital Infantil de Mexico, 77 (2): 47-53. doi:10.24875/BMHIM.20000039.

2. World Health Organization. Middle East respiratory syndrome coronavirus (MERS-CoV). https://www.who.int/ emergencies/mers-cov/en/. Accessed August 22, 2020.

3. Guarner, Jeannette. 2020. «Three Emerging Coronaviruses in Two Decades». American journal of clinical pathology, 153 (4): 420-421. doi:10.1093/ajcp/aqaa029.

4. Zhan W.Q., Li M.D., Xu M., Lu Y.B. 2020. «Successful treatment of COVID-19 using extracorporeal membrane oxygenation, a case report». Eur. Rev. Med. Pharmacol. Sci., 24 (6): 3385-3389. doi: 10.26355/eurrev_202003_20705.

5. Soldatov V.O., Kuberkina M.V., Silaeva Yu.Yu., Bruter A.V., Deykin A.V. 2020. «On the way from SARS-CoV-sensitive mice to murine COVID-10 model». Research Results in Pharmacology 6 (2): 1-7. https://doi.org/10.3897/rrpharmacology.6.53633.

6. Jin Y.H., Cai L., Cheng Z.S. 2020. «A rapid advice guideline for the diagnosis and treatment of 2019 novel coronavirus (2019-nCoV) infected pneumonia (standard version)». Mil. Med. Res. 7 (1): 4. doi:10.1186/s40779-020-0233-6.

\section{INFORMATION ABOUT THE AUTHORS}

Roman A. Bontsevich, MD, PhD, Associate Professor; Deputy Director of the Medical Center «Azbuka Zdorovya», Pulmonologist, Therapist, Clinical Pharmacologist, Associate Professor of the Department of Pharmacology and Clinical Pharmacology, NRU «Belgorod State University» (Belgorod National Research University), Belgorod, Russia

\section{ИНФОРМАЦИЯ ОБ АВТОРАХ}

Бонцевич Роман Александрович, кандидат медицинских наук, доцент кафедры фармакологии и клинической фармакологии медицинского института Белгородского государственного национального исследовательского университета, заместитель директора детского медицинского центра «Азбука здоровья», врач-пульмонолог, терапевт клиники «Любимый доктор», г. Белгород, Россия 
Yana R. Vovk, therapist, Postgraduate student of the Department of Pharmacology and Clinical Pharmacology, NRU «Belgorod State University» (Belgorod National Research University), Belgorod, Russia

\begin{abstract}
Anna V. Adonina, pediatrician of the medical center «Azbuka zdorovya», postgraduate student of the Department of Pharmacology and Clinical Pharmacology, NRU «Belgorod State University» (Belgorod National Research University), Belgorod, Russia
\end{abstract}

Liliya V. Solovyova, therapist, Resident doctor of the Department of Pharmacology and Clinical Pharmacology, NRU «Belgorod State University» (Belgorod National Research University), Belgorod, Russia
Вовк Яна Руслановна, аспирант кафедры фармакологии и клинической фармакологии медицинского института Белгородского государственного национального исследовательского университета, врачтерапевт клинико-диагностического центра «Медицина 31», г. Белгород, Россия

Адонина Анна Витальевна, аспирант кафедры фармакологии и клинической фармакологии медицинского института Белгородского государственного национального исследовательского университета, врач-педиатр детского медицинского центра «Азбука здоровья», г. Белгород, Россия

Соловьёва Лилия Владимировна, врачтерапевт, ординатор кафедры фармакологии и клинической фармакологии НИУ «Белгородский государственный университет», г. Белгород, Россия 